\title{
Controlled release of raloxifene by nanoencapsulation: effect on in vitro antiproliferative activity of human breast cancer cells
}

\author{
This article was published in the following Dove Press journal: \\ International Journal of Nanomedicine \\ 17 June 2014 \\ Number of times this article has been viewed
}

\section{Márcia Camponogara \\ Fontana \\ Aline Beckenkamp \\ Andréia Buffon \\ Ruy Carlos Ruver Beck}

Pharmaceutical Sciences Graduate Program, Faculty of Pharmacy, Federal University of Rio Grande do Sul (UFRGS), Porto Alegre, Rio Grande do Sul, Brazil
Correspondence: Ruy Carlos Ruver Beck Faculdade de Farmácia, Universidade Federal do Rio Grande do Sul (UFRGS), Av. Ipiranga, 2752, CEP 906I0-000, Bairro Santana, Porto Alegre,

Rio Grande do Sul, Brazil

Tel +55 5l 3308595 I

Fax +55 5I 33085090

Email ruy.beck@ufrgs.br
Abstract: Raloxifene hydrochloride (RH) is considered to be an antiproliferative agent of mammary tissue. The aim of this study was to investigate the effect of the encapsulation of RH in polymeric nanocapsules with anionic or cationic surface on its release profile and antiproliferative activity. They were prepared by interfacial deposition of preformed polymer, followed by wide physicochemical characterization. The in vitro RH release was assessed by the dialysis membrane method and the data analyzed by mathematical modeling. The antiproliferative effect on MCF-7 cell viability was investigated by 3-(4,5-dimethylthiazol-2-yl)-2,5-diphenyltetrazolium bromide assay as well as by counting viable cells. They had high encapsulation efficiency, low polydispersity, and nanometric mean size. Nanocapsules prepared with Eudragit ${ }^{\mathbb{R}}$ RS100 and Eudragit ${ }^{\circledR}$ S100 presented positive and negative zeta potentials, respectively. Drug release studies demonstrated controlled release of RH from anionic nanocapsules, which could be explained due to a stronger interaction of the drug to these nanocapsules and the larger amount of entrapped drug. On the other hand, this control was not observed from cationic nanocapsules due to the larger amount of drug adsorbed onto their surface. MCF-7 cell viability studies and cell counting showed that RH-loaded Eudragit ${ }^{\mathbb{R}}$ RS100 nanocapsules promote the best antiproliferative activity after 24 hours of treatment, whereas the best activity was observed for RH-loaded Eudragit ${ }^{\circledR}$ S100 nanocapsules after 72 hours. Furthermore, the combined treatment of these formulations improved the antiproliferative effect during the entire treatment.

Keywords: polymeric nanocapsules, physicochemical characterization, drug control release, antiproliferative effect, MCF-7

\section{Introduction}

Hormone therapy is used for the prevention and treatment of postmenopausal osteoporosis. Estrogen and progestogen replacement was accepted for decades, but their prolonged use may increase the risk of breast and endometrium cancer. ${ }^{1}$ Raloxifene hydrochloride $(\mathrm{RH})$ was synthesized to resist estrogen-dependent breast cancer proliferation through binding to the estrogen receptor of mammary tissue and blocking DNA transcription induced by estrogen, and is considered to be a chemopreventive agent. $^{2,3}$ This drug is a non-steroidal selective estrogen receptor modulator showing estrogenic effects on bone and the cardiovascular system, as well as antiestrogenic effects on breast tissue and endometrium. ${ }^{4}$ Furthermore, researchers showed that RH inhibits proliferation of hormone-dependent MCF-7 breast cancer cells and causes cell death via apoptosis and cell cycle arrest. ${ }^{5-8}$ 
After RH oral administration, it is absorbed from the gastrointestinal tract and due to first-pass metabolism (intestine and liver), its bioavailability is around $2 \% .{ }^{9}$ Nanoparticles can be uptaken by Peyer's patches after oral administration. ${ }^{10}$ The encapsulation of drugs in small particles is expected to promote an increase in drug bioavailability, and is an example of the application of nanotechnology on pharmaceutical development. Researchers have showed that higher drug concentrations are transported by polymeric nanocapsules to target sites or organs in comparison with free drugs. ${ }^{11,12}$

A higher in vitro intestinal permeability and an increase in the oral bioavailability of RH ( $3.5 \times$ higher) was observed for cationic solid lipid nanoparticles. ${ }^{13}$ Moreover, an in vitro study showed that a nanoemulsion with dispersed $\mathrm{RH}$ did not control the drug release, whereas a nanoemulsion with dissolved RH demonstrated slower drug release. However, a two-fold increase in RH uptake by endocrine organs (uterus, fallopian tubes, and ovaries) was observed in rats after oral administration of both nanoemulsions. ${ }^{14}$

Polymeric nanocapsules are drug carrier systems where the drug can be entrapped within the nanocarriers or adsorbed onto their surface. ${ }^{15}$ Bikiaris et al ${ }^{16}$ developed RH loadedpolymeric nanoparticles enabling an initial high release rate followed by very slow drug release rates. These particles (200-350 nm) were prepared from novel biodegradable polyesters (poly[ethylene succinate] and poly[propylene adipate]) by a coprecipitation method. The drug release rate was dependent on the melting point of the polyester used and the degree of crystallinity of the RH within the nanoparticles.

Nanoencapsulation of drugs has been considered an attractive and promising strategy to inhibit the proliferation of cancer cells. ${ }^{17-19}$ In addition, the enhanced antiproliferative response to combined treatment of two substances has been studied. A potential anticancer strategy with the combined use of raloxifene and trichostatin A (inhibitor to enhance the action of endocrine therapy in breast cancer cells) was observed on $\mathrm{MCF}-7$ breast cancer cells. ${ }^{8}$ Combined use increased the antiproliferative activity more than with either agent alone. Another study showed that the internalization of nanoparticles into MCF-7 cells was dependent upon layer type. ${ }^{20}$

In this context, the objective of this study was to encapsulate the RH into polymeric nanocapsules with either an anionic or cationic surface to evaluate the influence on in vitro drug release profile and antiproliferative activity in human breast cancer cell line (MCF-7). Taking into account the low oral bioavailability of RH and the small particle size of polymeric nanocapsules, these formulations can be useful as intermediate products for the production of pulmonary dosage forms and implants as well as aqueous intravenous dispersions.

\section{Materials and methods Materials}

Eudragit $^{\circledR}$ RS100 and Eudragit ${ }^{\circledR}$ S100 polymers were obtained from Evonik Industries Corp. (Essen, Germany). RH was supplied by Sequoia Research Products Ltd. (Pangbourne, UK). The caprylic/capric triglyceride mixture was acquired from Brasquim (Porto Alegre, Brazil), while sorbitan monostearate and polysorbate 80 were both obtained from Sigma-Aldrich Co. (St Louis, MO, USA). Acetone and ethanol were purchased from F. Maia Indústria e Comércio (São Paulo, Brazil) and Dinâmica Química Contemporânea Ltda (São Paulo, Brazil). Methanol (high-performance liquid chromatography [HPLC]-grade) was purchased from Tedia Co. (Fairfield, OH, USA). All chemicals and solvents were of pharmaceutical/HPLC grade and used as received. Dulbecco's Modified Eagle's Medium (DMEM), trypsin and 3-(4,5-dimethylthiazol-2-yl)-2,5-diphenyltetrazolium bromide (MTT) were obtained from Sigma-Aldrich Co. Fetal bovine serum (FBS) was supplied by Biogen Biotecnologia e Química (Porto Alegre, Brazil).

\section{Preparation of nanocapsule suspensions}

RH-loaded nanocapsules were prepared $(n=3)$ by interfacial deposition of preformed polymers. ${ }^{21}$ To evaluate the influence of surface charge of nanocapsules on drug release and antiproliferative activity, polymers with cationic and anionic charge were utilized (Eudragit ${ }^{\mathbb{B}}$ RS100 and Eudragit ${ }^{\circledR}$ S100, respectively). For the preparation of Eudragit ${ }^{\circledR}$ RS100 nanocapsules (RH-NC-RS), $250 \mathrm{mg}$ of polymer, $825 \mu \mathrm{L}$ caprylic/ capric triglyceride mixture $\left(31.35 \mathrm{mg} \cdot \mathrm{mL}^{-1}\right)$, and $6.25 \mathrm{mg}$ of RH were dissolved in $67 \mathrm{~mL}$ of acetone:water (15:1 volume per volume). For the preparation of Eudragit ${ }^{\circledR} \mathrm{S} 100$ nanocapsules (RH-NC-S), $250 \mathrm{mg}$ of polymer, $96 \mathrm{mg}$ of sorbitan monostearate $\left(3.84 \mathrm{mg} \cdot \mathrm{mL}^{-1}\right), 413 \mu \mathrm{L}$ caprylic/capric triglyceride mixture $\left(15.70 \mathrm{mg} \cdot \mathrm{mL}^{-1}\right)$, and $6.25 \mathrm{mg}$ of RH were dissolved in $67 \mathrm{~mL}$ of acetone:water (15:1 volume per volume). Each organic solution was added into $135 \mathrm{~mL}$ of an aqueous phase containing $191.5 \mathrm{mg}$ polysorbate 80 under magnetic stirring. Acetone was eliminated and the suspension was concentrated at $40^{\circ} \mathrm{C}$ under reduced pressure using a rotary evaporator (RII model; Büchi Corp., Flawil, Switzerland) to obtain a final volume of $25 \mathrm{~mL}\left(0.25 \mathrm{mg} \cdot \mathrm{mL}^{-1}\right.$ of $\left.\mathrm{RH}\right)$. Blank Eudragit ${ }^{\circledR}$ RS100 and Eudragit ${ }^{\circledR}$ S100 nanocapsule suspensions (NC-RS and NC-S, respectively) were prepared 
$(n=3)$ as described above, omitting the addition of the drug into the organic phase.

\section{Characterization of nanocapsule suspensions \\ Drug content, encapsulation efficiency, and $\mathrm{pH}$ determination}

To evaluate the drug content and encapsulation efficiency of the nanocapsules, it was necessary to validate an analytical methodology by HPLC, according to the International Conference on Harmonization guidelines. ${ }^{22}$ The system employed was a HPLC Shimadzu (Kyoto, Japan) equipped with a CBM-20A controller, an SPD-M20AV detector, a degasser DGU-20A5, a LC-20AT pump, a SIL-20A auto sampler, and a C18 column $(150 \mathrm{~mm} \times 4.6 \mathrm{~mm}, 5 \mu \mathrm{m}$ particle size, $110 \AA$ pore diameter; Discovery ${ }^{\circledR}$; Supelco Analytical, Sigma-Aldrich). The mobile phase at isocratic flow rate $\left(0.8 \mathrm{~mL} \cdot\right.$ minute $\left.^{-1}\right)$ consisted of 45:55 volume per volume methanol/water containing $0.2 \%$ glacial acetic acid over 12.0 minutes of run. The RH was detected at $287 \mathrm{~nm}$ and the injection volume was $20 \mu \mathrm{L}$. The method was linear $(r=0.9995)$ over the range of $1.0-20.0 \mu \mathrm{g} \cdot \mathrm{mL}^{-1}$, precise (RSD $<2 \%$ ), accuracy $(97.89 \% \pm 1.21 \%)$, and specific.

The drug content $\left(\mathrm{mg} \cdot \mathrm{mL}^{-1}\right)$ was determined by the extraction of the drug from the nanocapsule suspensions $(400 \mu \mathrm{L})$ in $10 \mathrm{~mL}$ of mobile phase (water:methanol 55:45 volume per volume, containing $0.2 \%$ glacial acetic acid). The samples were stirred for 30 minutes, sonicated for 30 minutes, filtered with a hydrophilic membrane $(0.45 \mu \mathrm{m}$, Millipore $^{\circledR}$; EMD Millipore, Billerica, MA, USA) and assayed by HPLC. The encapsulation efficiency (\%) was calculated by the difference between the total drug content and free drug (non-associated drug) in the nanocapsules. Free drug was analyzed by the ultrafiltration/centrifugation technique $\left(\right.$ Microcon $^{\circledR}$; MC Millipore 10,000 Da) at 4,000 rpm for 10 minutes. The $\mathrm{pH}$ measurements were determined directly in the nanocapsule suspensions, using a calibrated potentiometer (DM-22; Digimed, São Paulo, Brazil).

\section{Particle size, polydispersity indices, and zeta potential}

The formulations were initially evaluated by laser diffractometry (LD; Mastersizer 2000 ${ }^{\circledR}$, Malvern Instruments, Malvern, UK), without previous treatment of samples. The volume-weighted mean diameters $\left(D_{4.3}\right)$ and polydispersity (Span) were determined by this technique. ${ }^{23}$ The mean particle sizes and polydispersity indices $(n=3)$ were measured by photon correlation spectroscopy (PCS; Zetasizer
Nanoseries $^{\circledR}$, Malvern Instruments) after dilution of the nanocapsule suspensions $(20 \mu \mathrm{L})$ in $10 \mathrm{~mL}$ of purified water (1:500 volume per volume). The zeta potential was analyzed by electrophoretic mobility using the same instrument, after dilution of the formulations in $10 \mathrm{mM} \mathrm{NaCl}$ aqueous solution (1:500 volume per volume). ${ }^{24}$ Nanocapsules tracking analysis (NTA; NanoSight LM10 and NTA Analytical Software, Amesbury, UK) was used to estimate the particle size distribution, the number of particles per milliliter, and the presence of nanocrystals after appropriate dilution of the nanocapsule suspensions in purified water $(10,000 \times$ and $5,000 \times$ for Eudragit ${ }^{\circledR}$ RS100 and Eudragit ${ }^{\circledR}$ S100 nanocapsule suspensions, respectively). Furthermore, this analysis allowed the observation of the Brownian motion of the individual nanoparticles. ${ }^{25}$

\section{Physical stability}

The nanocapsule suspensions were evaluated by multiple light scattering (Turbiscan Lab ${ }^{\circledR}$; Formulaction, L’Union, France) immediately after preparation. This technique allows the observation of the phenomena of physical instability, such as sedimentation, creaming, coalescence, and flocculation. Each formulation $(20 \mathrm{~mL})$ was scanned from the bottom to the top of the glass cell ( $25 \mathrm{~mm}$ diameter, $55 \mathrm{~mm}$ height) at time intervals of 5 minutes over 60 minutes at $25^{\circ} \mathrm{C} .{ }^{26}$

\section{In vitro drug release study}

The RH release profiles from RH-NC-RS and RH-NC-S were studied by the dialysis membrane method $(n=3)$, with water:ethanol $\left(70: 30\right.$ volume per volume) at $37^{\circ} \mathrm{C}$ as the medium. Ethanol was added to maintain the sink condition. The medium was filtered $(0.45 \mu \mathrm{m}$ membrane $)$ and sonicated to remove air bubbles. The dialysis bag (12,000 Da cut-off; Sigma Aldrich) containing the nanocapsule suspensions $(2 \mathrm{~mL})$ was submerged inside a beaker containing the release medium $(200 \mathrm{~mL})$ under moderate stirring. A RH water:ethanol (1:1 volume per volume) solution (RH-Sol) at the same concentration of nanocapsule suspensions $\left(0.25 \mathrm{mg} \cdot \mathrm{mL}^{-1}\right)$ was also prepared to evaluate the diffusion of non-encapsulated RH across the dialysis bag $(\mathrm{n}=3)$. The external medium was collected $(0.75 \mathrm{~mL})$ from the system at predetermined time intervals, replaced by an equal volume of medium, and diluted in the mobile phase (1:1 volume per volume). The samples were assayed by HPLC according to the method previously described in the "Drug content, encapsulation efficiency, and pH determination" section. To evaluate the influence of the surface charge of RH-NC-RS (positive) and RH-NC-S (negative) on the RH 
release profiles, mathematical modeling (MicroMath ${ }^{\circledR}$ Scientist, St Louis, MO, USA) was carried out using the mono- and biexponential models. ${ }^{24,27}$ The model that best describes the drug release profile was selected through the model selection criteria (MSC), graphic adjustment, and the correlation coefficient. In order to obtain an additional parameter to compare the drug release behavior between the formulations, half-lives were calculated according to equation 1 :

$$
t_{1 / 2}=\frac{0.693}{k}
$$

where $k$ is the rate constant calculated from each release phase according to the best mathematical model.

Furthermore, to investigate the $\mathrm{RH}$ release mechanism from nanocapsules, $60 \%$ of the initial fraction of drug release was fitted to the Korsmeyer-Peppas model. ${ }^{28,29}$

\section{Maintenance of cell line}

The MCF-7 human breast cancer cell line was purchased from the American Type Culture Collection (Rockville, MD, USA). The cells were maintained in DMEM supplemented with $10 \% \mathrm{FBS}$ and the antibiotics penicillin/streptomycin $\left(0.5 \mathrm{U} \cdot \mathrm{mL}^{-1}\right)$, in an atmosphere of $5 \% \mathrm{CO}_{2} / 95 \%$ air at $37^{\circ} \mathrm{C}$. For the in vitro antiproliferative study and cell counting, the MCF-7 cells were plated in 96 -well plates at $2.5 \times 10^{3}$ cells per well in culture medium and cultured for 72 hours to reach semi-confluence. All materials were sterilized and the nanocapsule suspensions used were prepared under aseptic conditions.

\section{Drug exposure}

The cultures were treated with non-encapsulated RH solution (RH-S), RH-loaded nanocapsules (RH-NC-RS and RH-NC-S), or a mixture of these nanocapsule suspensions (1:1 volume per volume, RH-NC-M) at different concentrations $(1.0,2.5$, and $5.0 \mu \mathrm{M})$. The effect of the $\mathrm{RH}$ on MCF-7 cell proliferation was evaluated after 24 and 72 hours of incubation by MTT assay and cell counting. For preparation of $\mathrm{RH}-\mathrm{S}$, the drug was dissolved at $2 \mathrm{mg} \cdot \mathrm{mL}^{-1}$ in dimethyl sulfoxide (DMSO) and diluted in culture medium at the same drug concentration as the nanocapsule suspensions $\left(0.25 \mathrm{mg} \cdot \mathrm{mL}^{-1}\right)$. The maximum concentration of DMSO used to treat cells was $0.77 \%$. The control cells were treated with vehicle (V; 0.77\% DMSO in culture medium), blank nanocapsules (NC-RS, NC-S), and a mixture of these blank nanocapsule suspensions (1:1 volume per volume, NC-M). To evaluate the integrity of the nanocapsules after mixing the formulations (RH-NC-M and NC-M), particle size and polydispersity index were analyzed according that described in the "Particle size, polydispersity indices, and zeta potential" section.

\section{MCF-7 cell viability}

Cell viability was evaluated by the MTT assay, with three independent triplicate experiments. ${ }^{6}$ After 24 and 72 hours of incubation, each treatment was withdrawn and MTT solution $\left(0.5 \mathrm{mg} \cdot \mathrm{mL}^{-1}\right)$ was added to each well and plates were incubated at $37^{\circ} \mathrm{C}$ for 3 hours. At the end of the incubation time, precipitates are formed as a result of the reduction of the MTT salt to chromophore formazan crystals by the cells with metabolically active mitochondria. The optical density of solubilized crystals in DMSO was measured at $560 \mathrm{~nm}$ (test) and $630 \mathrm{~nm}$ (reference) on a microplate reader (Spectramax M2e and v 5.4.1; SoftMax Pro Software Interface; Molecular Devices, Sunnyvale, CA, USA). These values were converted to cell viability, expressed as the percentage of cell viability against the control. ${ }^{18}$

\section{Cell counting}

Cell viability was confirmed by trypan blue dye exclusion. ${ }^{30}$ After drug exposure (24 and 72 hours of incubation) the medium was removed, $50 \mu \mathrm{L}$ of $0.25 \%$ trypsin/ethylenediaminetetraacetic acid (EDTA) solution was added to each well, and the plates were incubated at $37^{\circ} \mathrm{C}$ for $10 \mathrm{~min}$ utes to detach the cells. After detachment of the cells, the DMEM $/ 10 \%$ FBS $(100 \mu \mathrm{L})$ was added and the viable cells counted (number of viable cells not stained by trypan blue) immediately by Neubauer chamber under optical microscope (CX21 model; Olympus, Tokyo, Japan). Before counting, the cells were diluted with trypan blue (1:1 volume per volume), which was used to selectively color dead cells in blue (trypan blue positive). The number of viable cells found in the treatments was compared to the number of viable cells in the control (cells in DMEM/10\% FBS only), which represents $100 \%$ cell viability. Therefore, we evaluated only viable cells without influence of the loss of dead cells in the step in which the culture medium was removed. The formula used is as follows:

Viability $(\%)=$ number of viable cells in the treatment $\times 100 /$ number of viable cells in the control. Results were expressed as a percentage of the control. ${ }^{30}$

It is noteworthy to mention that V (vehicle), NC-RS, and NC-S represent controls for the groups treated with RH-S, RH-NC-RS, and RH-NC-S, respectively. During cell viability assays, the control groups (V, NC-RS, and NC-S) did not 
show significant alterations in the proliferation of the cell line compared with the untreated group (control). The results were expressed in relation to the control culture without treatment (control), which represents $100 \%$ viability. ${ }^{30}$ Data were the averages of triplicate samples \pm standard deviation (SD) from three independent experiments.

\section{Statistical analysis}

Statistical analysis was performed using one-way analysis of variance (ANOVA) and Tukey's test. A difference was considered statistically significant at the level of $P \leq 0.05$. All formulations were prepared and analyzed in triplicate and values are presented as the mean $\pm \mathrm{SD}$.

\section{Results}

\section{Development of nanocapsule suspensions}

Figure 1 shows the granulometric profiles by LD of the drugloaded and blank nanocapsule suspensions $(n=3)$. Analyzing the size from $50 \%$ of the nanoparticles (Figure 1A), 50\% of the particles were lower than $78.00 \pm 0.01 \mathrm{~nm}, 82.33 \pm 2.52 \mathrm{~nm}$, $64.00 \pm 0.01 \mathrm{~nm}$, and $63.50 \pm 0.71 \mathrm{~nm}$ for NC-RS, RH-NC-RS, NC-S, and RH-NC-S, respectively. The volume-weighted mean diameters $\left(D_{4,3}\right)$ were $127 \pm 2 \mathrm{~nm}(\mathrm{NC}-\mathrm{RS}), 129 \pm 1 \mathrm{~nm}$ (RH-NC-RS), 166 \pm 6 nm (NC-S), and 187 \pm 11 nm (RH-NC-S; Figure 1B). Moreover, the polydispersity (Span) was lower than 2.0 for all formulations, with a narrow size distribution. However, formulations prepared with Eudragit ${ }^{\circledR}$ RS 100

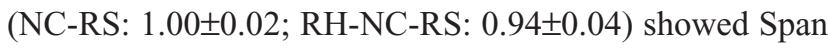
values lower than those formulations prepared with Eudragit ${ }^{\circledR}$ S100 (NC-S: 1.53 \pm 0.06 ; RH-NC-S: $1.73 \pm 0.02$ ).
The hydrodynamic diameters and polydispersity index were measured by PCS (Table 1). Through NTA analysis, it was possible to visualize the Brownian motion of the nanocapsules in suspension. Figure 2 shows a narrow size distribution for all formulations, with low polydispersity (Span; 0.76 for NC-RS, 0.74 for RH-NC-RS, 0.76 for NC-S, and 0.97 for RH-NC-S). The hydrodynamic diameters obtained by this technique were $198 \pm 69 \mathrm{~nm}, 156 \pm 45 \mathrm{~nm}$, $203 \pm 61 \mathrm{~nm}$, and $208 \pm 72 \mathrm{~nm}$ for NC-RS, RH-NC-RS, NC-S, and RH-NC-S, respectively. Moreover, the number of nanoparticles per milliliter of formulation was estimated by multiplying the number of particles in the sample by its dilution. The nanocapsule suspensions containing only oil in the core $\left(31.35 \mathrm{mg} \cdot \mathrm{mL}^{-1}\right.$; NC-RS: $10.76 \times 10^{12}$ particles $\cdot \mathrm{mL}^{-1}$; RH-NC-RS: $15.14 \times 10^{12}$ particles $\cdot \mathrm{mL}^{-1}$ ), had a larger number of particles than those with a core containing sorbitan monostearate $\left(3.84 \mathrm{mg} \cdot \mathrm{mL}^{-1}\right)$ and half of the oil (15.70 $\mathrm{mg} \cdot \mathrm{mL}^{-1}$; NC-RS: $5.94 \times 10^{12}$ particles $\cdot \mathrm{mL}^{-1}$; RHNC-RS: $6.69 \times 10^{12}$ particles $\left.\cdot \mathrm{mL}^{-1}\right)$. In addition, we evaluated the correlating scattering intensity and size distribution between NC-RS (Figure 2A) and RH-NC-RS (Figure 2B).

Further physicochemical characteristics (drug content, encapsulation efficiency, and $\mathrm{pH}$ ) of the formulations are showed in Table 2 . Both drug-loaded formulations presented a drug content of $0.25 \mathrm{mg} \cdot \mathrm{mL}^{-1}$ with low SD among the three different batches. Statistical analysis demonstrated that RH-NC-S has a higher drug encapsulation efficiency than RH-NC-RS as observed in Table $2(P \leq 0.05)$. All nanocapsule suspensions showed acidic $\mathrm{pH}$ (Table 2$)$, as expected for this kind of formulation containing Eudragit ${ }^{\mathbb{}}{ }^{29,31}$
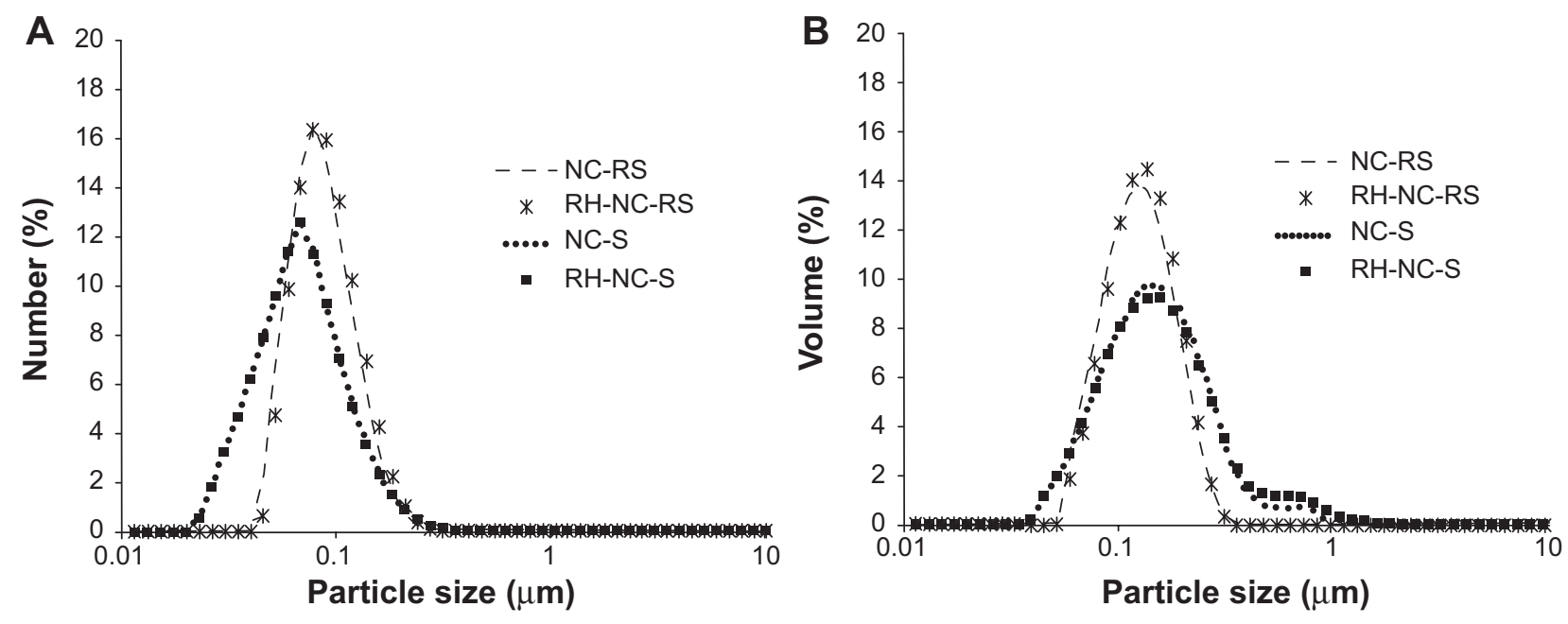

Figure I Particle size distributions of nanocapsules prepared with Eudragit ${ }^{\circledR}$ RSI00 (NC-RS and RH-NC-RS) or Eudragit ${ }^{\circledR}$ SI00 (NC-S and RH-NC-S) by laser diffraction. Notes: Measurements showing the (A) number (\%) and (B) volume (\%) of particles. NC-RS and NC-S refer to the blank Eudragit ${ }^{\circledR}$ RSI00 and Eudragit ${ }^{\circledR}$ SI00 nanocapsule suspensions, respectively, while RH-NC-RS and RH-NC-S refer to the Eudragit ${ }^{\circledR}$ RSI00 and Eudragit ${ }^{\circledR}$ SI 00 nanocapsules, respectively. Eudragit ${ }^{\circledR}$ RSI 00 and Eudragit $^{\circledR}$ SI 00 (Evonik Industries Corp., Essen, Germany). 
Table I Particle size, polydispersity index, and zeta potential of RH-loaded Eudragit ${ }^{\circledR}$ RSI00 nanocapsules (RH-NC-RS) or Eudragit ${ }^{\circledR}$ SI00 nanocapsules (RH-NC-S), and blank nanocapsules (NC-RS, NC-S) measured using photon correlation spectroscopy

\begin{tabular}{llll}
\hline Formulation & Particle size $(\mathbf{n m})$ & Polydispersity index & Zeta potential $(\mathbf{m V})$ \\
\hline NC-RS & $119 \pm 6^{\mathrm{a}}$ & $0.11 \pm 0.02^{\mathrm{a}}$ & $15.13 \pm 1.43^{\mathrm{a}}$ \\
RH-NC-RS & $133 \pm 3^{\mathrm{b}}$ & $0.10 \pm 0.02^{\mathrm{a}}$ & $12.21 \pm 1.34^{\mathrm{a}}$ \\
NC-S & $165 \pm 4^{\mathrm{c}}$ & $0.16 \pm 0.02^{\mathrm{b}}$ & $-13.73 \pm 1.94^{\mathrm{b}}$ \\
RH-NC-S & $178 \pm 2^{\mathrm{d}}$ & $0.18 \pm 0.01^{\mathrm{b}}$ & $-18.33 \pm 0.65^{\mathrm{c}}$ \\
\hline
\end{tabular}

Note: Means $(n=3)$, in the same column, with the same letter $(a, b, c$, or $d)$ are not significantly different $\left(P \leq 0.05\right.$, analysis of variance). Eudragit ${ }^{\circledR}$ RSI00 and Eudragit ${ }^{\circledR} S I 00$ (Evonik Industries Corp., Essen, Germany).

Figure 3 shows the graphical analysis of variation in the backscattering as a function of time. During the analysis ( 1 hour), no variation at the middle of the cell was observed and a small variation $(<4 \%)$ of the delta backscattering occurred at the bottom and top of the samples.

\section{In vitro drug release study}

The RH release profiles from the nanocapsule suspensions and the diffusion profile from the non-encapsulated drug (drug solution, RH-Sol) are shown in Figure 4. These profiles were modeled according to the mono and biexponential models. The model that best described the drug release profile was
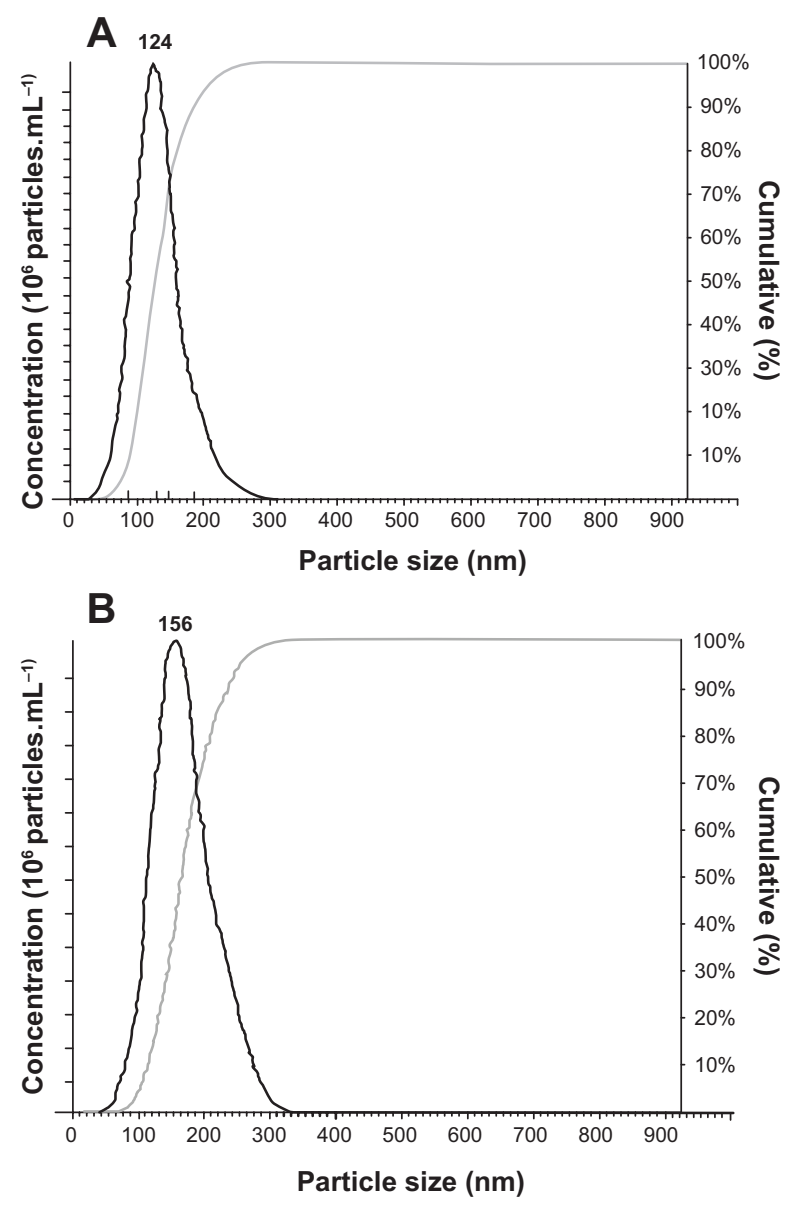

the biexponential model, selected through the higher values of MSC and the correlation coefficient (Table 3).

According to the Korsmeyer-Peppas model, RH release from RH-NC-RS had a regression coefficient of $0.9990 \pm 0.0003$, MSC of $5.27 \pm 0.29$, and a release exponent $(n)$ of $0.73 \pm 0.04$, whereas RH-NC-S had a regression coefficient of $0.9970 \pm 0.0009$, MSC of $4.78 \pm 0.31$, and $n$ of $0.60 \pm 0.01$.

\section{Evaluation of MCF-7 cell viability}

MTT assay and cell counting were used to evaluate the influence of the drug release control on the MCF-7 cell viability/
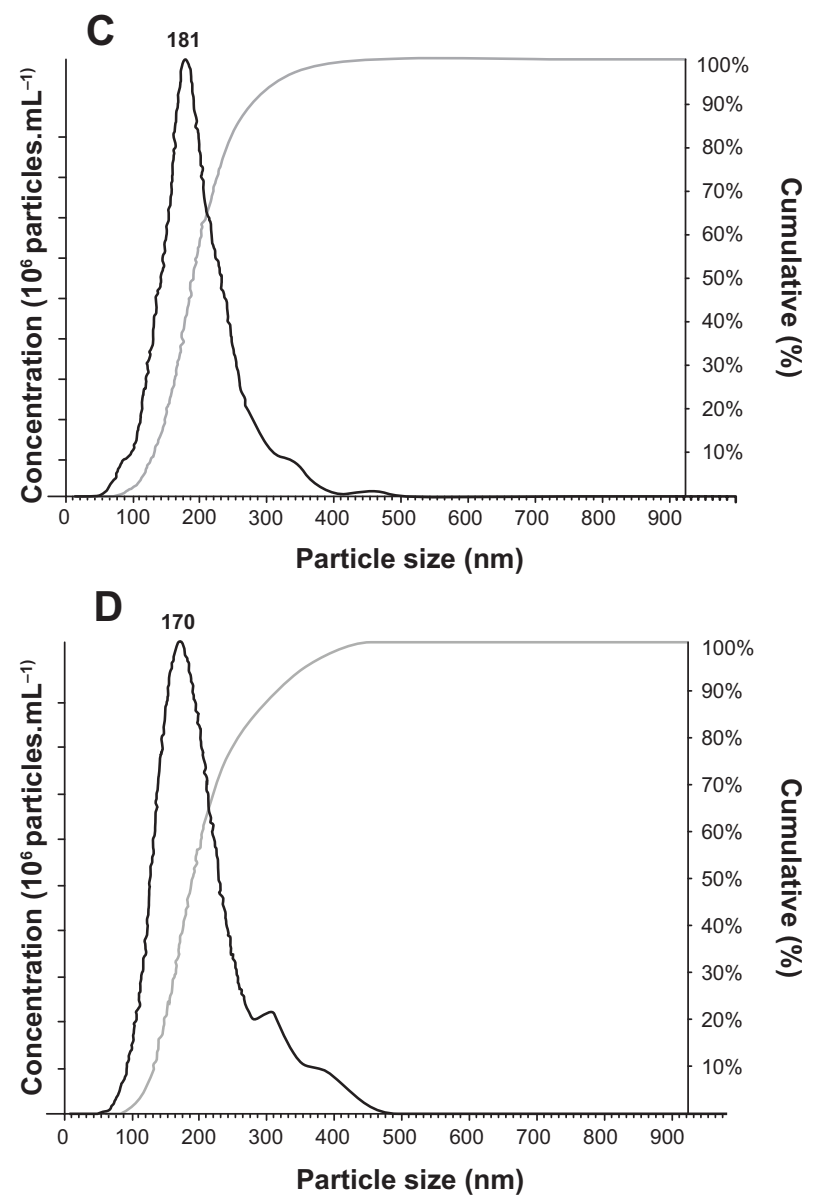

Figure 2 Nanocapsules tracking analysis plots of (A) NC-RS, (B) RH-NC-RS, (C) NC-S, and (D) RH-NC-S.

Notes: NC-RS and NC-S refer to the blank Eudragit ${ }^{\circledR}$ RSI00 and Eudragit ${ }^{\circledR}$ SI 00 nanocapsule suspensions, respectively, while RH-NC-RS and RH-NC-S refer to the Eudragit ${ }^{\circledR}$ RSI00 and Eudragit ${ }^{\circledR}$ SI00 nanocapsules, respectively. Eudragit ${ }^{\circledR}$ RSI00 and Eudragit ${ }^{\circledR}$ SIO0 (Evonik Industries Corp., Essen, Germany). 
Table 2 Drug content, encapsulation efficiency, and pH of RH-loaded nanocapsules of Eudragit RSI00 (RH-NC-RS) and Eudragit SI00 (RH-NC-S), and blank nanocapsules (NC-RS, NC-S)

\begin{tabular}{llll}
\hline Formulation & Drug content $\left(\mathbf{m g} \cdot \mathbf{m L}^{-1}\right)$ & Encapsulation efficiency $(\%)$ & pH \\
\hline NC-RS & - & - & $5.97 \pm 0.07^{\mathrm{a}}$ \\
RH-NC-RS & $0.25 \pm 0.01$ & $92.27 \pm 0.57^{\mathrm{a}}$ & $5.00 \pm 0.12^{\mathrm{b}}$ \\
NC-S & - & - & $4.38 \pm 0.09^{\mathrm{c}}$ \\
RH-NC-S & $0.25 \pm 0.01$ & $99.35 \pm 0.03^{\mathrm{b}}$ & $3.60 \pm 0.10^{\mathrm{d}}$
\end{tabular}

Note: Means $(n=3)$, in the same column, with the same letter (a, b, c, or $d)$ are not significantly different $\left(P \leq 0.05\right.$, analysis of variance). Eudragit ${ }^{\circledR}$ RSI 00 and Eudragit ${ }^{\circledR}$ SI 00 (Evonik Industries Corp., Essen, Germany).

proliferation after treatment with RH-loaded nanocapsules. Three concentration of drug $(1.0,2.5$, and $5.0 \mu \mathrm{M})$ were investigated for 24 and 72 hours of treatment (Figures 5A-D). The cell viability of the treated groups was calculated in relation to the control culture without treatment (control), which represents $100 \%$ viability. During MTT assay and cell counting, the control groups (V, NC-RS, and NC-S) did not show significant alterations in the proliferation of the cell line when compared with the untreated groups (control) $(P>0.05)$.

After 24 and 72 hours of treatment, all RH treatments led to a significant decrease in cell viability in comparison with their respective control group ( $P \leq 0.05)$, except for the group treated with $1.0 \mu \mathrm{M}$ of RH-S for 24 hours $(P>0.05)$. After 24 hours of treatment in the
MTT assay (Figure 5A), all concentrations of RH-NC-RS $(1.0 \mu \mathrm{M}: 85.32 \% \pm 1.66 \% ; 2.5 \mu \mathrm{M}: 79.31 \% \pm 0.92 \%$; and $5.0 \mu \mathrm{M}$ : $76.05 \% \pm 1.85 \%$ ) and RH-NC-S at $2.5 \mu \mathrm{M}$ $(94.99 \% \pm 0.42 \%)$ and $5.0 \mu \mathrm{M}(93.60 \% \pm 0.83 \%)$ showed significant reduction in cell viability compared to their respective control groups treated with the drug solution (RH-S; $1.0 \mu \mathrm{M}$ : 98.75\% $\pm 0.66 \%$; $2.5 \mu \mathrm{M}$ : 97.54\% $\pm 0.53 \%$; and $5.0 \mu \mathrm{M}$ : $96.20 \% \pm 0.52 \% ; P \leq 0.05)$.

After 72 hours of treatment in the MTT assay (Figure 5B), the groups treated with RH-NC-S at different concentrations $(1.0 \mu \mathrm{M}$ : $89.68 \% \pm 0.28 \%$; $2.5 \mu \mathrm{M}$ : $84.90 \% \pm 1.15 \%$; and $5.0 \mu \mathrm{M}: 78.96 \% \pm 0.57 \%)$ promoted a significant decrease in cell viability compared to their respective control groups treated with the drug solution (RH-S;

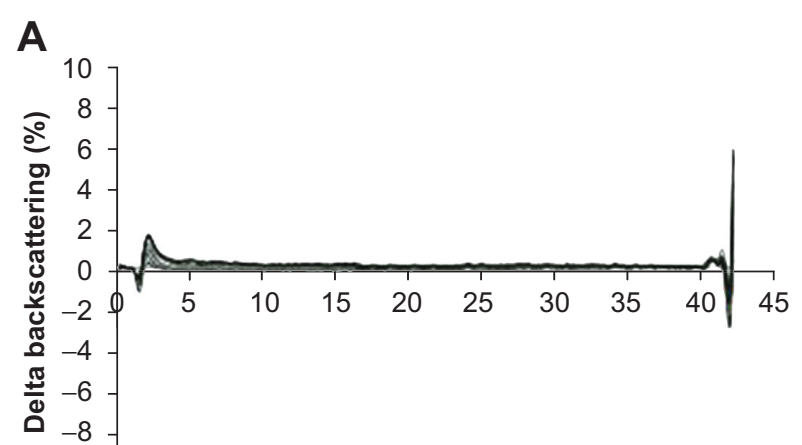

-10 Height $(\mathrm{mm})$

B

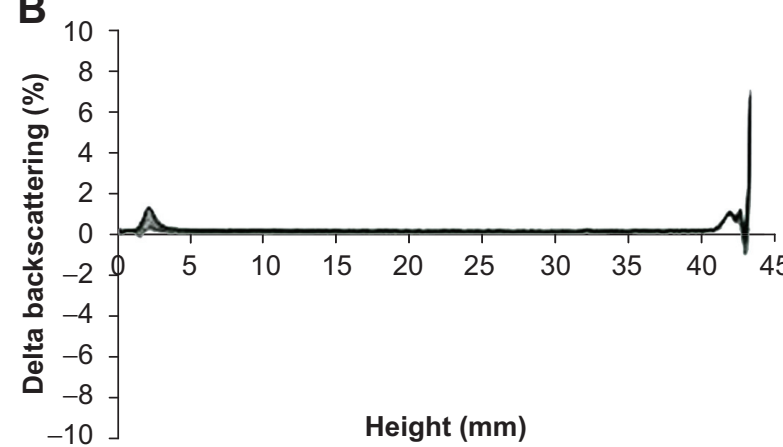

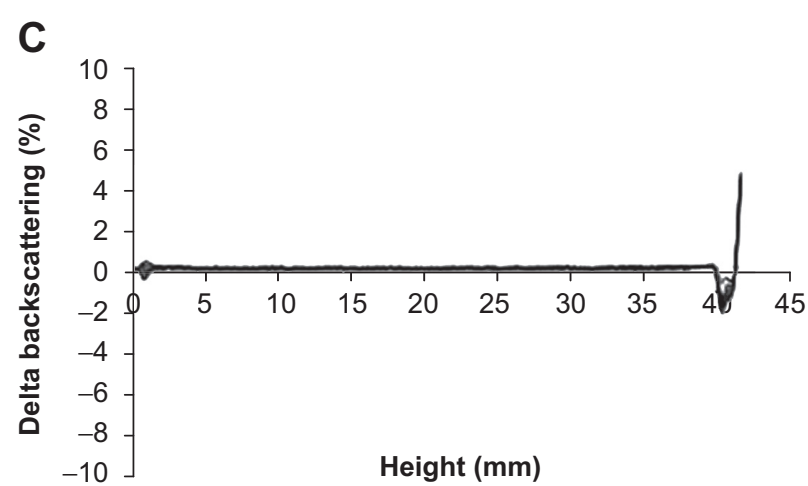

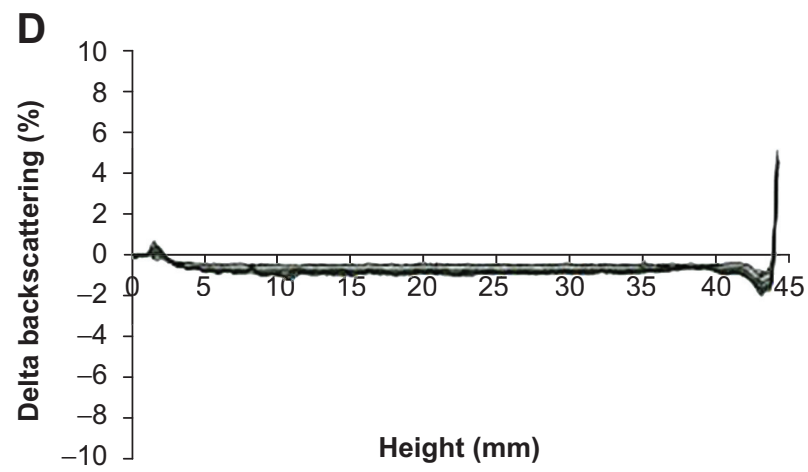

Figure 3 Delta backscattering (\%) profiles of (A) NC-RS, (B) RH-NC-RS, (C) NC-S, and (D) RH-NC-S.

Notes: The bottom and top of the cuvette are displayed on the left and right sides of the images. NC-RS and NC-S refer to the blank Eudragit ${ }^{\circledR}$ RSI00 and Eudragit ${ }^{\circledR}$

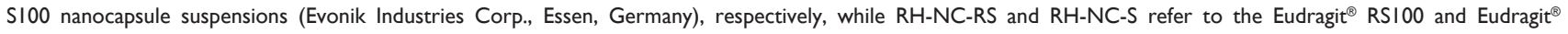
SI00 nanocapsules, respectively. 
Table 3 Observed rate constants, correlation coefficients, MSC, and half-lives $\left(t_{1 / 2}\right)$ obtained by fitting of $\mathrm{RH}$ release from different nanocarriers (RH-NC-RS, RH-NC-S)

\begin{tabular}{lll}
\hline & RH-NC-RS & RH-NC-S \\
\hline Monoexponential & & \\
$\quad k\left(\mathrm{~min}^{-1}\right)$ & $0.0137 \pm 0.000 \mathrm{I}$ & $0.0019 \pm 0.000 \mathrm{I}$ \\
$r$ & $0.9877 \pm 0.000 \mathrm{I}$ & $0.9910 \pm 0.0008$ \\
MSC & $2.5691 \pm 0.0364$ & $2.8406 \pm 0.0074$ \\
Biexponential & & \\
$k_{1}\left(\mathrm{~min}^{-1}\right)$ & $0.0242 \pm 0.001 \mathrm{I}^{\mathrm{a}}$ & $0.0067 \pm 0.0007^{\mathrm{b}}$ \\
$k_{2}\left(\mathrm{~min}^{-1}\right)$ & $0.0026 \pm 0.0003^{\mathrm{a}}$ & $0.0008 \pm 0.000 \mathrm{I}^{\mathrm{b}}$ \\
$a$ & $0.7593 \pm 0.0308^{\mathrm{a}}$ & $0.3258 \pm 0.0702^{\mathrm{b}}$ \\
$b$ & $0.2522 \pm 0.0274^{\mathrm{a}}$ & $0.6663 \pm 0.0683^{\mathrm{b}}$ \\
$r$ & $0.9987 \pm 0.0004$ & $0.9995 \pm 0.000 \mathrm{I}$ \\
MSC & $5.3047 \pm 0.2620$ & $6.3063 \pm 0.2288$ \\
$t_{1 / 2} k_{1}$ (minutes) & $28.72 \pm 1.26^{\mathrm{a}}$ & $104.01 \pm 10.98^{\mathrm{b}}$ \\
$t_{1 / 2} k_{2}$ (minutes) & $268.12 \pm 29.17^{\mathrm{a}}$ & $928.12 \pm 87.50^{\mathrm{b}}$ \\
\hline
\end{tabular}

Notes: Means, in the same line, with the same letter $(a, b)$ are not significantly different $(P \leq 0.05$, analysis of variance). RH-NC-RS and RH-NC-S refer to the Eudragit $^{\circledR}$ RSI00 and Eudragit ${ }^{\circledR}$ SI00 nanocapsules (Evonik Industries Corp., Essen, Germany), respectively.

Abbreviations: MSC, model selection criteria; RH, raloxifene hydrochloride.

$1.0 \mu \mathrm{M}: 93.79 \% \pm 0.69 \%$; $2.5 \mu \mathrm{M}: 90.11 \% \pm 0.88 \%$; and $5.0 \mu \mathrm{M}: 85.92 \% \pm 0.31 \% ; P \leq 0.05)$. This decrease was also observed for the group treated with RH-NC-RS at the concentration of $5.0 \mu \mathrm{M}(82.79 \% \pm 2.00 \%)$. Cells treated with RH-NC-RS at concentrations of $1.0 \mu \mathrm{M}$ and $2.5 \mu \mathrm{M}$ did not show significant modifications on cell growth after 72 hours compared to their respective control groups treated with the drug solution $(P>0.05)$. The results obtained in cell counting (Figures 5C and D) for all treatments after 24 and

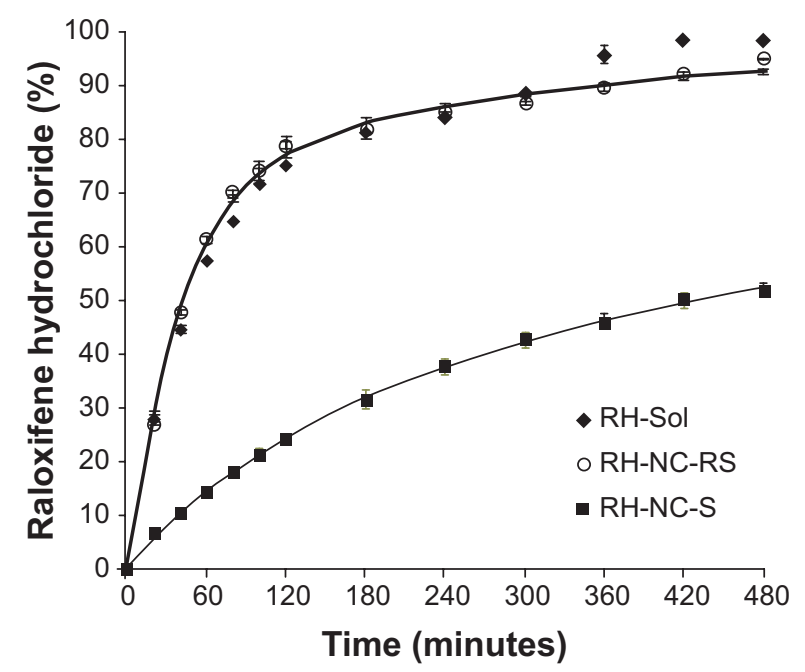

Figure 4 In vitro RH release profile from nanocarriers (RH-NC-RS, RH-NC-S) and from drug solution (RH-Sol) by the dialysis bag method $(n=3)$ at $37^{\circ} \mathrm{C}$.

Notes: The lines correspond to the fitting to the biexponential equation. RH-NCRS and RH-NC-S refer to the Eudragit ${ }^{\circledR}$ RSI00 and Eudragit ${ }^{\circledR}$ SI00 nanocapsules (Evonik Industries Corp., Essen, Germany), respectively.

Abbreviation: $\mathrm{RH}$, raloxifene hydrochloride.
72 hours were similar to results observed in the MTT assays $(P>0.05)$.

The MTT assay and cell counting were also performed by mixing the formulations RH-NC-S and RH-NC-RS (RH$\mathrm{NC}-\mathrm{M})$ at the same concentrations $(1.0,2.5$, and $5.0 \mu \mathrm{M})$. As a control, the mixture of NC-RS and NC-S 1:1 volume per volume (NC-M) was employed. After mixing the nanocapsule formulations, the NC-M and RH-NC-M groups presented low polydispersity $(0.15 \pm 0.01$ and $0.13 \pm 0.01$, respectively) and the particle size was the mean size of individual nanocapsule formulations ( $146 \pm 3 \mathrm{~nm}$ and $159 \pm 1 \mathrm{~nm}$, respectively). Thus, no agglomeration occurred between nanocapsules presenting opposite surface charges.

For the MTT assay and viable cell counting (Figures 6A and B), a larger decrease in cell viability in the groups treated with RH-NC-M $(1.0,2.5$, and $5.0 \mu \mathrm{M})$ was observed when compared to its respective group treated with RH-S (1.0, 2.5, and $5.0 \mu \mathrm{M} ; P \leq 0.05)$.

\section{Discussion}

RH-loaded and blank nanocapsules were prepared using polymers with different charges, which appeared as a milky bluish liquid that exhibited the Tyndall effect. A unimodal particle size distribution was observed and was obtained by LD analysis for all formulations, regardless of the presence of the drug or type of polymer. According to the European Legislation, these formulations can be considered nanomaterials, since $50 \%$ of the particles are $<100 \mathrm{~nm} .{ }^{32}$ Furthermore, the presence of the drug did not affect the particle size distribution. The morphological characteristics of polymeric nanocapsules prepared with Eudragit ${ }^{\mathbb{B}}$ RS100 and Eudragit ${ }^{\mathbb{B}}$ S100 have already been reported in the literature. ${ }^{29,31}$ In these reports, the authors confirmed the formation of spherical nanocapsules with similar qualitative and quantitative composition, as well as the same method of preparation (interfacial deposition of preformed polymer).

All formulations had nanoscopic particle sizes as measured by PCS. Polydispersity indices were $<0.20$, confirming the results (low Span values) obtained by LD. As expected, due to the surface charge at the particle/ water interface, the nanocapsule suspensions prepared with Eudragit $^{\mathbb{1}}$ RS100 showed positive zeta potential and nanocapsule suspensions prepared with Eudragit ${ }^{\circledR}$ S100 showed negative zeta potential, which is in agreement with previous studies. ${ }^{29,33}$ The mean particle size obtained by NTA was in agreement with those obtained by LD and PCS.

Regarding the particle numbers, it appears that more polymeric nanocapsules were formed when the amount 

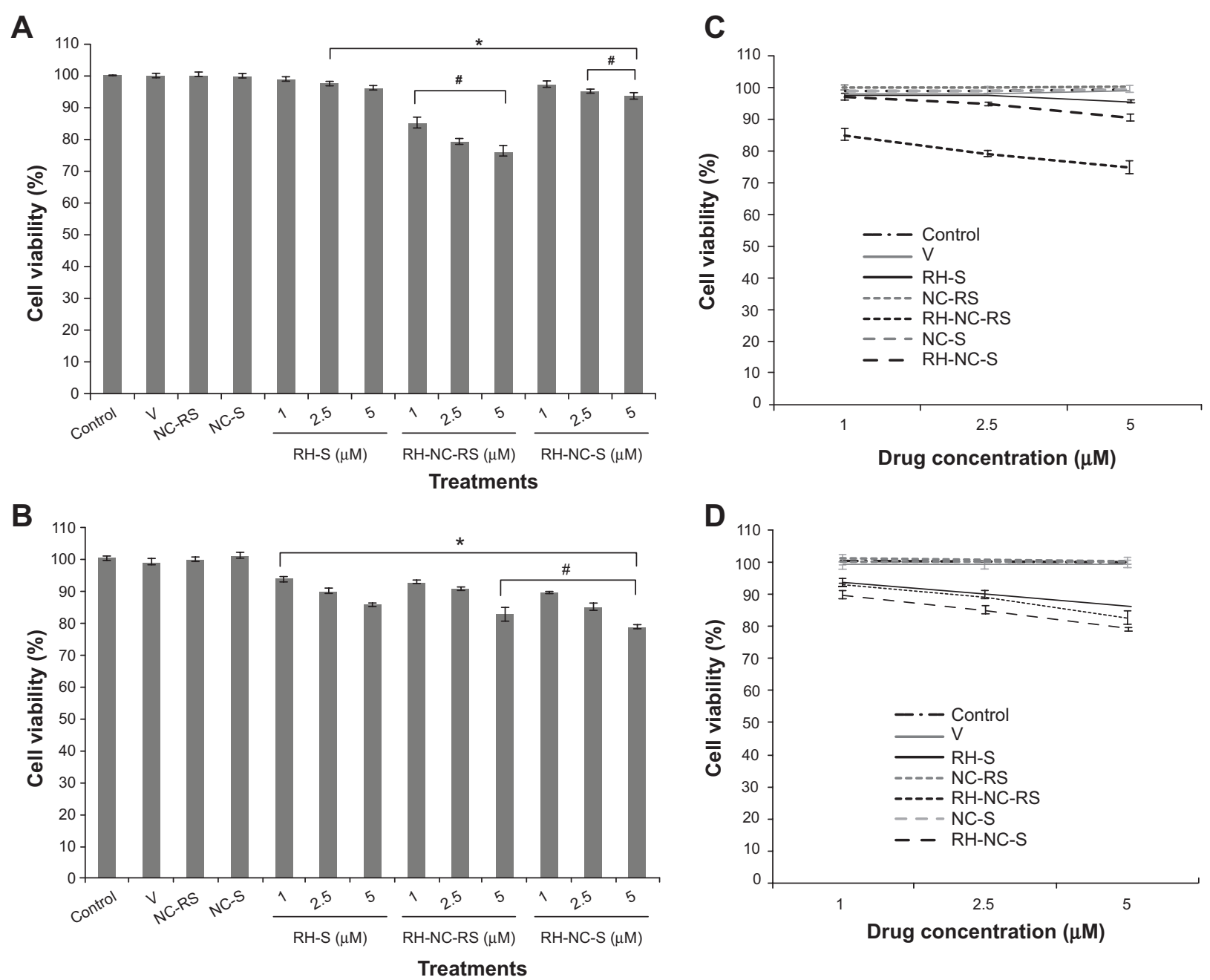

Figure 5 Effect of RH solution (RH-S) and RH-loaded nanocapsule formulations (RH-NC-RS and RH-NC-S) on MCF-7 cell viability.

Notes: The cultures were treated with 1.0, 2.5, or $5.0 \mu \mathrm{M}$ of RH for 24 (A and $\mathbf{C})$ and 72 (B and D) hours. (A) and (B) are data from the MTT assay. (C) and (D) are data from the cell counting method. Cultures were also treated with vehicle $(\mathrm{V})$ and RH-unloaded nanocapsules (NC-RS and NC-S). *Indicates significant differences compared to the respective control group; "Indicates significant differences compared to the respective control group treated with drug solution (ANOVA followed by Tukey's test, $P \leq 0.05)$. RH-NC-RS and RH-NC-S refer to the Eudragit ${ }^{\circledast}$ RSI 00 and Eudragit ${ }^{\circledast} \mathrm{SI} 00$ nanocapsules (Evonik Industries Corp., Essen, Germany), respectively. Abbreviations: ANOVA, analysis of variance; MTT, 3-(4,5-dimethylthiazol-2-yl)-2,5-diphenyltetrazolium bromide; RH, raloxifene hydrochloride.
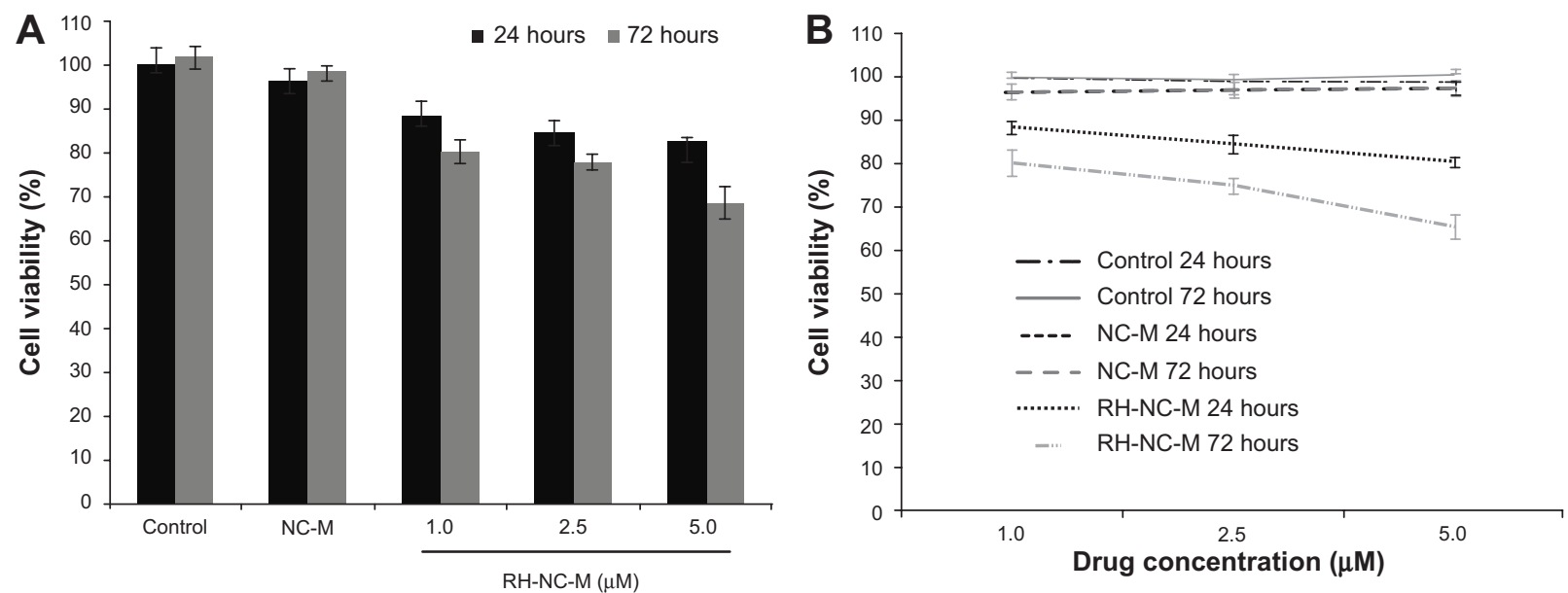

Treatments

Figure 6 Effect of RH-loaded nanocapsules mixture (RH-NC-M) on MCF-7 cell viability.

Notes: The cells were treated with 1.0, 2.5, or $5.0 \mu \mathrm{M}$ of RH nanoencapsulated for 24 and 72 hours; (A) are data from the MTT assay and (B) are data from the cell counting method.

Abbreviations: RH, raloxifene hydrochloride; MTT, 3-(4,5-dimethylthiazol-2-yl)-2,5-diphenyltetrazolium bromide. 
of oil in the nanocapsule suspensions of the cationic polymers (NC-RS and RH-NC-RS) was increased. ${ }^{34}$ However, recently, Jäger et $\mathrm{al}^{35}$ and Venturini et $\mathrm{al}^{26}$ showed that excessive oil may lead to simultaneous formation of polymeric nanocapsules and nanoemulsion. Furthermore, in order to reject the hypothesis that the higher numbers of particles in the nanocapsule suspensions of Eudragit ${ }^{\circledR}$ RS100 were related to the formation of nanocrystals due to the presence of excessive raloxifene, scattering intensity and size distribution between NC-RS and RH-NC-RS were correlated. According to Jornada et $\mathrm{al}^{25}$ scattering intensity of colloids varies with the presence of drug nanocrystals. When comparing these formulations, blank nanocapsules show a similar plot by NTA as RH-loaded nanocapsules and we can suggest that drug nanocrystals do not exist in our formulations.

Concerning the further physicochemical properties, higher encapsulation efficiency was obtained for RH-NC-S, which can be explained by the presence of sorbitan monostearate in this formulation, probably due to increasing affinity of the drug for the core of the nanocapsules or by the stronger interaction of the drug with the Eudragit ${ }^{\circledR} \mathrm{S} 100$ polymer (explained by the presence of $\mathrm{N}^{+}$and $\mathrm{COO}^{-}$groups, respectively). NC-S has a lower $\mathrm{pH}$ than NC-RS, due to the presence of the carboxylic acid groups in Eudragit ${ }^{\mathbb{B}} \mathrm{S} 100$. RH has three $\mathrm{p} K_{\mathrm{a}}$ values $(8.95,9.83$, and 10.91) and remains ionized in acidic medium. ${ }^{36}$ The addition of $\mathrm{RH}$ in both nanocapsule formulations resulted in a decrease of $\mathrm{pH}$ values $(P \leq 0.05)$. For nanocapsules prepared with Eudragit ${ }^{\circledR} \mathrm{RS}$, this could be explained by the electrostatic interaction of $\mathrm{N}^{+}$from the polymer with $\mathrm{O}^{-}$from the drug, which releases protons $\left(\mathrm{H}^{+}\right)$and acidifies the aqueous phase. On the other hand, for nanocapsules prepared with Eudragit ${ }^{\circledR}$ S100, we suggest that $\mathrm{COO}^{-}$from the polymer interacts with $\mathrm{N}^{+}$from the drug, as proposed for the higher encapsulation efficiency of these formulations, which releases $\mathrm{H}^{+}$and thus, lowers the $\mathrm{pH}$ of the formulation. Furthermore, the $\mathrm{pH}$ of the raloxifene aqueous solution is $6.17 \pm 0.15$, which is higher than the $\mathrm{pH}$ of the formulations and confirms that the acidic $\mathrm{pH}$ of the drug-loaded formulations is influenced by the qualitative and quantitative composition of the formulation. Blank formulation, prepared without raloxifene, also showed acidic $\mathrm{pH}$ values.

The physical instability of the nanocapsule suspensions was evaluated by multiple light scattering, allowing observation of reversible (sedimentation, creaming) and irreversible (coalescence and flocculation) destabilization phenomena. The backscattering results demonstrate the physical stability of the developed formulations, which can be explained by the presence of the polysorbate 80 on the particle-water interface, acting as a steric stabilizer. This physical stability of formulations was also explained by the efficient particle size control, and the qualitative and quantitative optimization of the formulation components. ${ }^{26}$ The absence of physical instability of the RH-loaded formulations reinforces our previous suggestion about the absence of drug crystals in these formulations.

In the next step, $\mathrm{RH}$ release from the nanocapsules was evaluated in comparison with a $\mathrm{RH}$ solution (nonencapsulated RH). RH-Sol and RH-NC-RS showed that $98.27 \% \pm 0.51 \%$ and $95.09 \% \pm 0.24 \%$ of the drug was released after 480 minutes, respectively. The in vitro $\mathrm{RH}$ release profile from RH-NC-RS is similar to RH-Sol as shown in Figure 4. This formulation has a higher proportion of drug adsorbed onto the polymeric wall of the nanocapsules $(75 \%$; Table 3) enabling easy drug release from the nanocarriers and its diffusion through the dialysis bag at a similar rate to the non-encapsulated RH (RH-Sol). On the other hand, the RH-NC-S released only $51.97 \% \pm 1.10 \%$ of the drug after the same length of time, showing the best drug release control. The type of polymer and the presence of sorbitan monostearate (RH-NC-S) influenced the release profile. Nanocapsule suspensions prepared from different polymeric walls (polycaprolactone [PCL], poly(lactic-co-glycolic acid) [PLGA], polylactic acid [PLA], Eudragit ${ }^{\circledR}$ RS100, or Eudragit ${ }^{\circledR}$ S100) are known as good candidates for modulating the release of lipophilic substances. ${ }^{24,27-29,33}$ For a deeper evaluation of the influence of the surface charge on the $\mathrm{RH}$ release profiles, whether positive (RH-NC-RS) or negative (RH-NC-S), the nanocapsule suspensions were modeled according to the mono and biexponential models.

The best fit to the experimental data was obtained by the biexponential equation (Table 3), regardless of the surface charge of the nanocapsules (cationic or anionic: RH-NC-RS and RH-NC-S, respectively). This model describes a burst release phase followed by a sustained release phase; it also fit the release obtained for nanocapsules previously prepared with Eudragit ${ }^{\circledR}$ RS100 and Eudragit ${ }^{\circledR}$ S100. ${ }^{29,33}$ A RH control release from lyophilized polyester nanospheres using dissolution apparatus I (United States Pharmacopeia [USP]) was also previously observed. ${ }^{16}$ The kinetic experiment demonstrated that rate constants for the burst phase $\left(k_{1}\right)$ and sustained phase $\left(k_{2}\right)$ for RH-NC-S were lower compared to RH-NC-RS $(P \leq 0.05)$. According to the calculated parameters ( $a$ and $b)$, approximately $67 \%$ of the drug was entrapped within the RH-NC-S and only 33\% was superficially adsorbed on these nanocapsules. On the other hand, the RH-NC-RS has around $25 \%$ and $75 \%$ of drug entrapped and adsorbed on nanocapsules, respectively. The higher proportion of drug entrapped 
within RH-NC-S (67\%) enabled better release control compared with RH-NC-RS (25\%). Thus, the higher proportion of drug superficially adsorbed on the RH-NC-RS (75\%) enabled an easy drug release compared with RH-NC-S (33\%). This difference in the release profile can be also discussed in terms of half-life. Compared with RH-NC-RS, RH-NC-S increased the RH half-life release values 3.62 times and 3.46 times for burst and sustained phases, respectively.

Furthermore, in this case, an interaction between RH and the polymeric wall of nanocapsules may be an important factor to control the drug release rate. The slower drug release observed from RH-NC-S can be explained by a stronger interaction of the drug with the Eudragit ${ }^{\circledR}$ S100 polymer. Accordingly, RH could be more easily released from Eudragit ${ }^{\mathrm{B}}$ RS100 nanocapsules than from Eudragit ${ }^{\circledR}$ S100 nanocapsules. Moreover, a previous study has demonstrated that the viscosity of the core increases with the presence of sorbitan monostearate and consequently decreases the drug diffusive flux ${ }^{35}$ as observed for the nanocapsules prepared with Eudragit ${ }^{\circledR}$ S100. Furthermore, according to KorsmeyerPeppas modeling, as the $n$ was between 0.43 and 0.85 , it can be suggested that the mechanism of drug release was according to an anomalous transport. ${ }^{28}$ Thus, relaxation of the polymer chains occurs during the drug release from both formulations, regardless of the polymer wall of nanocapsules as well as RH Fickian diffusion through these walls. ${ }^{29}$

$\mathrm{RH}$ is known to promote an antiproliferative effect on MCF-7 breast cancer cells. ${ }^{5-8}$ In this study, both formulations showed different drug release profiles, as discussed above. In this scenario, for the next step, we evaluated the influence of the drug release rate from the different formulations on MCF-7 cell viability by comparing it to a RH solution (non-encapsulated RH). Eudragit ${ }^{\circledR}$ RS100, like other cationic polymers, is known for its cytotoxic effects, ${ }^{37}$ but this effect was not observed in our study, probably due to its low concentration in the formulations (1\%).

The results of treatment with RH-S after 24 and 72 hours are in agreement with the literature data that showed an antiproliferative effect of raloxifene on MCF-7 cells for treatments up to $5.0 \mu \mathrm{M}$ in concentration. ${ }^{8}$ However, an increase in the antiproliferative effect was observed by the RH nanoencapsulation. Treatments with RH-NC-RS ( $75 \%$ of $\mathrm{RH}$ adsorbed in nanocapsules and does not control the drug release) led to a higher reduction in cell viability after 24 hours compared with treatments with RH-NC-S (33\% of RH adsorbed in nanocapsules and higher drug controlled release), as previously discussed. On the other hand, better performance in the cytotoxicity assay was observed for RH-NC-S after 72 hours. In order to confirm the MTT assay results, cell viability was assessed by trypan blue dye exclusion. It was observed that treatment with nanocapsule suspensions with superior RH controlled release (RH-NC-S) caused a greater decrease in cell viability after 72 hours than those groups treated with RH-NC-RS, which showed faster drug release. Thus, RH-NC-RS and RH-NC-S showed the best effects in 24 and 72 hours, respectively. Due to these results, a hypothesis was postulated where the viability of the MCF-7 cells could be even more decreased after 24 and 72 hours by combining treatment (RH-NC-S and RHNC-RS). In order to evaluate this hypothesis, RH-NC-RS and RH-NC-S were mixed 1:1 volume per volume (RH-NC-M) and MCF-7 cells were treated.

After 24 and 72 hours, the groups treated with RH-NC-M showed significant decrease in cell proliferation compared to the untreated group (control) and to the group treated with NC-M, regardless of the concentration (Figures 6A and B). In the MTT assay (Figure 6A), cell viability was lower after 72 hours $(1.0 \mu \mathrm{M}: 80.08 \% \pm 2.77 \%, 2.5 \mu \mathrm{M}$ : $77.78 \% \pm 1.82 \%$, and $5.0 \mu \mathrm{M}$ : $68.52 \% \pm 3.84 \%)$ than 24 hours $(1.0 \mu \mathrm{M}$ : $88.23 \% \pm 3.37 \%, 2.5 \mu \mathrm{M}: 84.44 \% \pm 2.75 \%$, and $5.0 \mu \mathrm{M}$ : $82.29 \% \pm 1.13 \%$ ) for treatment with RH-NC-M, independent of the concentration. Moreover, a greater decrease in cell viability in groups treated with RH-NC-M $(1.0,2.5$, and $5.0 \mu \mathrm{M})$ was observed compared to the groups treated with RH-loaded nanocapsules (RH-NC-RS and RH-NC-S; $P \leq 0.05$ ).

Based on these results, our hypothesis could be validated in that RH-NC-RS causes an initial antiproliferative effect (24 hours) and that RH-NC-S maintains this effect until 72 hours. These results are important findings for correlating the modulation of $\mathrm{RH}$ release from nanocarriers and its antiproliferative effect on MCF-7 cells.

The results obtained from viable cell counting for RHNC-M treatments $(1.0,2.5$, and $5.0 \mu \mathrm{M})$ after 24 and 72 hours (Figure 6B) were similar to results observed in the MTT assay $(P>0.05)$, confirming that nanoencapsulation increases the antiproliferative effect of RH on breast cancer cells.

Although the influence of the drug release profile from nanocapsules was shown on the antiproliferative effects of the different formulations in MCF-7 cells, the influence of the particles' charge on their cellular uptake cannot be refuted. However, Martínez et a ${ }^{38}$ showed that both positive and negative nanoparticles can be internalized by the MCF-7 cell line. Further in vitro studies on the influence of cellular uptake need to be conducted to analyze the influence of particle charge on the antiproliferative effect of the formulations developed in this work (RH-NC-RS and RH-NC-S). 
The formulations were prepared under aseptic conditions to evaluate cell viability in our studies. However, these nanocapsules should be sterile for in vivo administration. Studies using sterilization by autoclaving would be needed to evaluate the possibility of sterilization of these nanoparticles while still maintaining their stability and integrity. ${ }^{39,40}$ On the other hand, at this stage, it is possible to obtain sterile nanocapsule formulations by preparing them under aseptic conditions.

\section{Conclusion}

The type of polymeric wall and the presence of the surfactant in the core influences the RH release profile from nanocapsules prepared with Eudragit ${ }^{\circledR}$ RS100 and Eudragit ${ }^{\circledR}$ S100. Formulations prepared with the anionic polymer (Eudragit ${ }^{\circledR}$ S100) showed better controlled release of RH as evidenced by the higher percentage of drug in their inner core. On the other hand, nanocapsules prepared with the cationic polymer (Eudragit ${ }^{\circledR}$ RS100) showed a larger amount of drug adsorbed onto the nanocapsules. In vitro MCF-7 cell viability and cell counting showed that RH-NC-RS and RH-NC-S have the best antiproliferative effects after 24 and 72 hours, respectively, compared to their non-encapsulated forms. Furthermore, the mixture of the two formulations promoted lower cell growth during all treatments as compared to cells treated individually with each formulation. The nanoencapsulation of RH in the polymeric nanocapsules improved its antiproliferative effect on breast cancer cells and this effect could be modulated by the choice of the polymer and thus, control the RH release rate from nanocapsules. The nanocapsule suspensions may be suggested as suitable alternatives for the development of oral, pulmonary, and intravenous dosage forms.

\section{Acknowledgments}

MC Fontana and A Beckenkamp are grateful to CAPESBrazil and CNPq-Brazil for their Doctoral and Master fellowships, respectively. The authors acknowledge the financial support of CAPES, CNPq, FAPERGS, PRONEM and PRONEX FAPERGS/CNPq, Rede Nanobiotec CAPES and INCT_IF CNPq/Brazil.

\section{Disclosure}

The authors report no conflicts of interest in this work.

\section{References}

1. Lee WL, Chao HT, Cheng MH, Wang PH. Rationale for using raloxifene to prevent both osteoporosis and breast cancer in postmenopausal women. Maturitas. 2008;60(2):92-107.

2. Bayrak E, Lambrecht FY, Durkan K, Yilmaz O. In vitro evaluation, biodistribution in rats of radiolabeled raloxifene. Appl Radiat Isot. 2010;68(1):33-36.
3. Dai X, Wu J. Selective estrogen receptor modulator: raloxifene. J Reprod Contracept. 2011;22(1):51-60.

4. Kayath MJ. Raloxifeno e osteoporose: revisão de um novo modulador seletivo do receptor de estrógeno. Arq Bras Endocrinol Metab. 1999; 43(6):433-441. Portuguese.

5. Liu H, Lee ES, Gajdos C, et al. Apoptotic action of 17beta-estradiol in raloxifene-resistant MCF-7 cells in vitro and in vivo. $J$ Natl Cancer Inst. 2003;95(21):1586-1597.

6. Sookvanichsilp N, Boonleang C. Alendronate, raloxifene and tibolone inhibit the proliferation-stimulating activity of 17beta-estradiol in MCF-7 cells. MU J Pharm Sci. 2005;32(3-4):55-65.

7. Hodges-Gallagher L, Valentine CD, El Bader S, Kushner PJ. Estrogen receptor beta increases the efficacy of antiestrogens by effects on apoptosis and cell cycling in breast cancer cells. Breast Cancer Res Treat. 2008;109(2):241-250.

8. Tu Z, Li H, Ma Y, et al. The enhanced antiproliferative response to combined treatment of trichostatin A with raloxifene in MCF-7 breast cancer cells and its relevance to estrogen receptor $\beta$ expression. Mol Cell Biochem. 2012;366(1-2):111-122.

9. Morello KC, Wurz GT, DeGregorio MW. Pharmacokinetics of selective estrogen receptor modulators. Clin Pharmacokinet. 2003;42(4): 361-372.

10. Shakweh M, Ponchel G, Fattal E. Particle uptake by Peyer's patches: a pathway for drug and vaccine delivery. Expert Opin Drug Deliv. 2004; 1(1):141-163.

11. Haas SE, Bettoni CC, de Oliveira LK, Guterres SS, Dalla Costa T. Nanoencapsulation increases quinine antimalarial efficacy against Plasmodium berghei in vivo. Int J Antimicrob Agents. 2009;34(2):156-161.

12. Frozza RL, Bernardi A, Paese K, et al. Characterization of transresveratrol-loaded lipid-core nanocapsules and tissue distribution studies in rats. J Biomed Nanotechnol. 2010;6(6):694-703.

13. Patel BD, Modi RV, Thakkar NA, Patel AA, Thakkar PH. Development and characterization of solid lipid nanoparticles for enhancement of oral bioavailability of Raloxifene. J Pharm Bioallied Sci. 2012;4(Suppl 1): S14-S16.

14. Elsheikh MA, Elnaggar YS, Gohar EY, Abdallah OY. Nanoemulsion liquid preconcentrates for raloxifene hydrochloride: optimization and in vivo appraisal. Int J Nanomedicine. 2012;7:3878-3802.

15. Kumari A, Yadav SK, Yadav SC. Biodegradable polymeric nanoparticles based drug delivery systems. Colloid Surf B Biointerfaces. 2010;75(1): $1-18$.

16. Bikiaris D, Karavelidis V, Karavas E. Novel biodegradable polyesters. Synthesis and application as drug carriers for the preparation of raloxifene $\mathrm{HCl}$ loaded nanoparticles. Molecules. 2009;14(7):2410-2430.

17. Zhao L, Feng SS. Enhanced oral bioavailability of paclitaxel formulated in vitamin E-TPGS emulsified nanoparticles of biodegradable polymers: in vitro and in vivo studies. $J$ Pharm Sci. 2010;99(8):3552-3560.

18. Zanotto-Filho A, Coradini K, Braganhol E, et al. Curcumin-loaded lipid core nanocapsules as a strategy to improve pharmacological efficacy of curcumin in glioma treatment. Eur J Pharm Biopharm. 2013;83: 156-167.

19. Bernardi A, Frozza RL, Hoppe JB, et al. The antiproliferative effect of indomethacin-loaded lipid-core nanocapsules in glioma cells is mediated by cell cycle regulation, differentiation, and the inhibition of survival pathways. Int $J$ Nanomedicine. 2013;8:711-728.

20. Bazylińska U, Pietkiewicz J, Saczko J, et al. Nanoemulsion-templated multilayer nanocapsules for cyanine-type protosensitizer delivery to human breast carcinoma cells. Eur J Pharm Sci. 2012;47(2): 406-420.

21. Fessi H, Puisieux F, Devissaguet JP, inventors; Centre National De La Recherche Scientifique (Cnrs), applicant. Procédé de préparation des systèmes colloïdaux dispersibles d'une substance sous forme de nano-capsules. European Patent EP0274961 A1. 1988 Jul 20.

22. International Conference on Harmonization (ICH). Validation of Analytical Procedures: Text and Methodology Q2 (R1). Geneva, Switzerland: International Federation of Pharmaceutical Manufacturers and Associations; 2005. 
23. Bender EA, Adorne MD, Colomé LM, Abdalla DSP, Guterres SS, Pohlmann AR. Hemocompatibility of poly( $\square$-caprolactone) lipid-core nanocapsules stabilized with polysorbate 80-lecithin and uncoated or coated with chitosan. Int J Pharm. 2012;426(1-2):271-279.

24. Almeida JS, Lima F, Ros SD, Bulhões LO, de Carvalho LM, Beck RCR. Nanostructured systems containing rutin: in vitro antioxidant activity and photostability studies. Nanoscale Res Lett. 2010;5(10): 1603-1610.

25. Jornada DS, Fiel LA, Bueno K, et al. Lipid-core nanocapsules: mechanism of self-assembly, control of size and loading capacity. Soft Matter. 2012;8:6646-6656.

26. Venturini CG, Jäger E, Oliveira CP, et al. Formulation of lipid core nanocapsules. Colloid Surf A Physicochem Eng Aspects. 2011;375(2011): 200-208.

27. Fontana MC, Coradini K, Guterres SS, Pohlmann AR, Beck RC. Nanoencapsulation as a way to control the release and to increase the photostability of clobetasol propionate: influence of the nanostructured system. J Biomed Nanotechnol. 2009;5(3):254-263.

28. Fontana MC, Coradini K, Pohlmann AR, Guterres SS, Beck RC. Nanocapsules prepared from amorphous polyesters: effect on the physicochemical characteristics, drug release, and photostability. J Nanosci Nanotechnol. 2010;10(5):3091-3099.

29. Contri RV, Kaiser M, Poletto FS, Pohlmann AR, Guterres SS. Simultaneous control of capsaicinoids release from polymeric nanocapsules. J Nanosci Nanotechnol. 2011;11(3):2398-2406.

30. Liu H, Kurtoglu M, Cao Y, et al. Conversion of 2-deoxyglucoseinduced growth inhibition to cell death in normoxic tumor cells. Cancer Chemother Pharmacol. 2013;72(1):251-262.

31. Schaffazick SR, Siqueira IR, Badejo AS, et al. Incorporation in polymeric nanocapsules improves the antioxidant effect of melatonin against lipid peroxidation in mice brain and liver. Eur J Pharm Biopharm. 2008;69(1):64-71.
32. Official Journal of the European Union. Legislation. English edition, L275. Volume 54; October 20, 2011. ISSN 1977-0677.

33. Hoffmeister CR, Durli TL, Schaffazick SR, et al. Hydrogels containing redispersible spray-dried melatonin-loaded nanocapsules: a formulation for transdermal-controlled delivery. Nanoscale Res Lett. 2012;7(1):251.

34. Losa C, Marchal-Heussler L, Orallo F, Vila Jato JL, Alonso MJ. Design of new formulations for topical ocular administration: polymeric nanocapsules containing metipranolol. Pharmaceut Res. 1993;10(1):80-87.

35. Jäger E, Venturini CG, Poletto FS, et al. Sustained release from lipidcore nanocapsules by varying the core viscosity and the particle surface area. J Biomed Nanotechnol. 2009;5(1):130-140.

36. Teeter JS, Meyerhoff RD. Environmental fate and chemistry of raloxifene hydrochloride. Environ Toxicol Chem. 2002;21(4):729-736.

37. Aksungur P, Demirbilek M, Denkbaş EB, Vandervoort J, Ludwig A, Unlü N. Development and characterization of Cyclosporine A loaded nanoparticles for ocular drug delivery: cellular toxicity, uptake, and kinetic studies. J Control Release. 2011;151(3):286-294.

38. Martínez A, Olmo R, Iglesias I, Teijón JM, Blanco MD. Folate-targeted nanoparticles based on albumin and albumin/alginate mixtures as controlled release systems of tamoxifen: synthesis and in vitro characterization. Pharm Res. 2014;31(1):182-193.

39. Cavalli R, Caputo O, Carlotti ME, Trotta M, Scarnecchia C, Gasco MR. Sterilization and freeze-drying of drug-free and drug-loaded solid lipid nanoparticles. Int J Pharm. 1997;148(1):47-54.

40. Memisoglu-Bilensoy E, Hincal AA. Sterile, injectable cyclodextrin nanoparticles: effects of gamma irradiation and autoclaving. Int $J$ Pharm. 2006;311(1-2):203-208.
International Journal of Nanomedicine

\section{Publish your work in this journal}

The International Journal of Nanomedicine is an international, peerreviewed journal focusing on the application of nanotechnology in diagnostics, therapeutics, and drug delivery systems throughout the biomedical field. This journal is indexed on PubMed Central, MedLine, CAS, SciSearch $\AA$, Current Contents $₫ /$ Clinical Medicine,

\section{Dovepress}

Journal Citation Reports/Science Edition, EMBase, Scopus and the Elsevier Bibliographic databases. The manuscript management system is completely online and includes a very quick and fair peer-review system, which is all easy to use. Visit http://www.dovepress.com/ testimonials.php to read real quotes from published authors. 